\title{
DETERMINING THE CONTENT OF Cd, Cu, Pb AND Zn IN THE LEAVES OF DANDELION (TARAXACUM OFFICINALE WEBB.) AND IN THE SOIL BY ICP-OES
}

\author{
Dragan Velimirović1 ${ }^{1}$ Biljana Kaličanin ${ }^{1}$, Milan Stojković ${ }^{2}$, Snežana Tošić ${ }^{2}$
}

\begin{abstract}
Dandelion (Taraxacum officinale Webb.) is a plant capable of accumulating a certain quantity of metals. The aim of this study was to determine the content of $\mathrm{Cd}, \mathrm{Cu}, \mathrm{Pb}$ and $\mathrm{Zn}$ in dandelion leaves and soil that have been sampled from different locations. One group of samples has been influenced by pollution sources of these metals and the other one has not been exposed to the pollutants. The amount of metals in the tested samples has been determined by inductively coupled plasma optical emission spectrometry (ICP-OES).The content of detected metals was higher in leaves and soil samples that were exposed to the negative effect of environmental pollutants, compared to those samples that were not under the influence of contamination sources. The increased content of detected metals in the samples of dandelion leaves that were under the influence of the pollutant may be the result of a synergistic effect, soil, on which this plant species thrives, and the air, that is contaminated by the effects of motor traffic and other forms of pollutants. The results of this study have shown that dandelion can provide a data of environmental pollution by the content of detected metals in its tissue. As dandelion is used in human nutrition, and since heavy metals ( $\mathrm{Pb}, \mathrm{Cd})$ with cumulative and toxic effects have been detected in it, it is necessary, in order to protect human health, to check the presence and content of these metals in the dandelion plant that is used in human nutrition.
\end{abstract}

Acta Medica Medianae 2020;59(1):23-30.

Key words: dandelion, metals, soil, pollutants, ICP-OES

\footnotetext{
${ }^{1}$ University of Niš, Faculty of Medicine, Department of Pharmacy, Niš, Serbia

2University of Niš, Faculty of Sciences and Mathematics, Department of Chemistry, Niš, Serbia
}

Contact: Dragan Velimirović

81 Dr. Zoran Djindjić Blvd., 18000 Niš, Serbia

E-mail: dragan.velimirovic@medfak.ni.ac.rs

\section{Introduction}

The development and advance of technology, in all spheres of life, are processes that have been rapidly evolving since the industrial revolution in the $18^{\text {th }}$ century. Today we are witnesses of a huge and constant development of technological and industrial processes that leads to a significant improvement in the life of an individual in all social aspects. Unfortunately, such an unstoppable advance, with all the benefits, also brings different negative effects, that can also cause very serious and unsolvable problems for all of the living beings on the planet.
Global and local pollution of the environment that harms all the living organisms is definitely one of the biggest problems, and a direct result of constant industrial development of the human species.

Environmental pollutants are of organic and non-organic origin. They can have a bigger or smaller negative effect on the living world. In the big group of non-organic pollutants cadmium and lead must be pointed out. They are especially dangerous, as they are toxic, even in small quantities (1). An increased amount of metals in the environment, taking into consideration the fact that they are ecotoxicological danger, creates a need to find and develop economical chemical methods whose aim would be to detect the presence of metal in tested samples and discover the dangers that living organisms are exposed to because of these pollutants. One of the ways to detect these pollutants is to identify the organisms that, thanks to their ability to accumulate different metals, can give adequate information about the assessment of environmental contamination with these metals. These organisms that give quantitative data that is connected to the environment, for example, how much pollutants are present at the tested location. Every kind of organism that is distributed over a wider geographical area, that is toxitolerant to a large number of metals 
and that can accumulate them, can be used for metal content determination. These accumulated metal contents reflect the contamination quantity when compared to monitored variables (2).

A large number of different plants shows the capability to accumulate various metals from the environment, and this characteristic qualifies them as adequate indicators of environmental pollution with some toxic metals. Herbaceous plants are capable of accumulating a significant quantity of different metals, and one of those is also dandelion (Taraxacum officinale Webb.). Dandelion is a plant species that produces new leaves every year. It is widespread in nature and farmland and one of its characteristics is that it is capable of accumulating traces of elements $(2,3)$. By reviewing the literature, it is possible to see that dandelion has been used in a number of studies as preferable plant species for determining the level of environmental pollution, based on the metal content in its tissue (4-9). Numerous studies have shown that there is a connection between the quantity of metals present in the tested part of the environment (soil, air, water...) and the detected amount of these elements in dandelion tissue $(4,5,10)$. Detected quantities of metals in dandelion samples that have been collected at different distances from the metals pollution source (landfills, roads, industrial plants...) have shown that the amount of metals in the tissue of this plant depends on the distance from the pollution source. Those dandelion samples that have been taken near the pollutant had increased levels of metals compared to the samples taken from areas that haven't been exposed to them $(2,4,8$, 11).

\section{Aim of the study}

Taking into consideration these facts, the aim of this study was to determine the content of individual metals ( $\mathrm{Cd}, \mathrm{Cu}, \mathrm{Pb}$ and $\mathrm{Zn}$ ) in dandelion leaves that have been sampled at 6 locations on the territory of the city of Niš and that have been close to the pollution source with these metals (main city roads, a gas station). In order to compare the level of detected metals in dandelion leaves that have been sampled near the pollution source, the level of these metals has also been determined in dandelion leaves samples from 3 locations (local excursion spots) that haven't been impacted by motor traffic. Furthermore, since the amount of detected elements also depends on the chemical composition of soil where this plant grows, the amount of $\mathrm{Cd}, \mathrm{Cu}, \mathrm{Pb}$ and $\mathrm{Zn}$ has been determined in the soil from these locations. The amount of cadmium, copper, lead and zinc in the tested samples of soil and dandelion has been determined by inductively coupled plasma optical emission spectrometry (ICP-OES).

\section{Materials and methods}

\section{Reagents and chemicals}

- ICP multi-element standard solution (Ultra scientific (USA)), $\mathrm{Y}=20.00 \pm 0.10 \mathrm{mg} / \mathrm{L}$;

- 65\% nitric acid, p.a. (Merck, Darmstad); stad);

- 36\% hydrochloric acid, p.a. (Merck, Darm-

- 30\% hydrogen peroxide (Fluka) and

- High purity water, conductivity $0.05 \mu \mathrm{Scm}$ 1 (MicroMed high purity water system, TKA Wasseraufbereitungssysteme $\mathrm{GmbH}$ ).

Vials of PVC material were used to store the test samples. In order to remove traces of possibly present metals, the vials were previously washed with $5 \%$ nitric acid, then tap water and finally with deionized water.

\section{Instrumentation}

The overall analysis was conducted by an iCAP 6000 inductively coupled plasma optical emission spectrometer (Thermo Scientific, Cambridge, United Kingdom) which combines an Echelle optical design and a charge injection device (CID) solid state detector. iTEVA operating software for iCAP 6000 series was used to control all functions of the instrument. The optimal operating parameters of instrument are given in Table 1.

Table 1. The optimal operating parameters for ICP-OES measurement

\begin{tabular}{||lc|}
\hline Parameter & \\
\hline \hline Flush Pump Rate & $100 \mathrm{rpm}$ \\
Analysis Pump Rate & $50 \mathrm{rpm}$ \\
RF power & $1150 \mathrm{~W}$ \\
Nebulizer gas & $0.7 \mathrm{~L} / \mathrm{min}$ \\
Coolant Gas Flow & $12 \mathrm{~L} / \mathrm{min}$ \\
Plasma View & Axial mode \\
\hline
\end{tabular}

Analytical balance (Mettler Toledo) was used to measure the mass.

Samples mineralization was carried out in a VIMS electric (Serbia) furnace equipped with a microprocessor programmatic temperature control IVIGOS3123 ( $\left.\pm 1^{\circ} \mathrm{C}\right)$.

A pH meter (Hanna Instruments, USA) was used to determine the soil $\mathrm{pH}$ value. 


\section{Samples}

The content of $\mathrm{Cd}, \mathrm{Cu}, \mathrm{Pb}$ and $\mathrm{Zn}$ was determined in leaves of dandelion (Taraxacum officinale Webb.), which were sampled from different localities in the area and surrounding of the city of Niš. Nine sites (marked 1-9) considered for this study are shown in Table 2. The leaves of dandelion plants of the same developmental stage, were cut with a plastic knife and than were placed in plastic bags. Samples of dandelion, grown near the streets, with high traffic intensity (samples 1 to 6 ) were taken at two different distances from the street, $1 \mathrm{~m}$ (a sam- ples) and $5 \mathrm{~m}$ (b samples). In Table 2, the localities of dandelion samples that were not under the impacted to traffic, were marked from 7 to 9 . The coordinates of all points from which the samples were collected were determined by GPS.

The soil samples were collected from the same locations as dandelion leaves samples. Soil samples were collected just at the bottom of each sampled plant by plastic spatula. Only the first $5 \mathrm{~cm}$ of soil was collected in the root area. Each soil sample was placed in a separate plastic bag and stored at a room temperature.

Table 2. Site identification and its coordinates

\begin{tabular}{|c|c|c|}
\hline No. & Site & Coordinates \\
\hline 1 & Street & N4319'11.7300" E2154'0.0324" \\
\hline 2 & Street & N4318'57.9348" E2154'55.2816" \\
\hline 3 & Street & N4319'14.3940" E2154'1.0080" \\
\hline 4 & Roundabout & 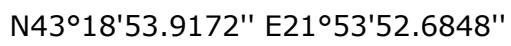 \\
\hline 5 & Street near the railway & 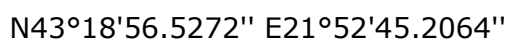 \\
\hline 6 & Street near the gass station & N4319'0.9624" E2153'35.7720" \\
\hline 7 & Park „Čair" & N4318'0.4612" E21이'21.6720" \\
\hline 8 & Park „Bubanj” & N431' $15.4224^{\prime} " \mathrm{E} 21^{\circ} 52^{\prime} 21.2160^{\prime \prime}$ \\
\hline 9 & Natural Park „Kamenički vis” & N4324'45.3168" E2156'5.1468" \\
\hline
\end{tabular}

\section{Samples preparation}

\section{Mineralization of plant material}

The plants leaves were cut with a plastic knife and stored in plastic bags. Then, they were washed with deionized water and left to dry in the air. After air drying, they were dried in a kiln at a temperature of $70{ }^{\circ} \mathrm{C}$. The samples were then homogenized; a mass of $3.0 \mathrm{~g}$ of the sample was analyzed. For the detection of metals, the samples were prepared by a dry digestion method (12). Portion of each sample was then weighed and heated at a temperature of $600{ }^{\circ} \mathrm{C}$ for a period of $12 \mathrm{~h}$ in porcelain crucible. For complete mineralization of the samples, $1 \mathrm{ml}$ of $65 \%$ $\mathrm{HNO}_{3}$ was added; the samples were heated to dryness and then returned into the furnace. The obtained ash was digested in $3 \mathrm{ml}$ of $65 \% \mathrm{HNO}_{3}$ and filtered through a Whatman No 541 tape in a $50 \mathrm{ml}$ flask.

\section{Pseudo-total cation content determination in soil samples}

Soil samples were collected with a plastic ladle, in the immediate vicinity of the dandelion plant from a depth of $0-10 \mathrm{~cm}$. All of the soil samples were spread on plastic trays in fume cupboards and allowed to dry at ambient temperature for 8 days. The pseudo-total amounts of $\mathrm{Cd}, \mathrm{Cu}, \mathrm{Pb}$ and $\mathrm{Zn}$ were determined by the digestion of the samples using $\mathrm{HNO}_{3}-\mathrm{HCl}$ (aqua regia) by means of the conventional wet acid digestion method (13).

\section{Soil $\mathrm{pH}$ value determination}

The dry soil sample was homogenized in the spindle and diluted through the sieve $0.5 \mathrm{~mm}$, then weighed $20 \mathrm{~g}$ and transferred to a $50 \mathrm{ml}$ flask, then poured with $20 \mathrm{ml}$ of deionized water. The sample than was covered with watch glass and mixed for 5 minutes, then left to stand for one hour. Subsequently, the suspension was filtered. Measurement of the $\mathrm{pH}$ value was carried out $\mathrm{pH}$-metric (Hanna Instruments, USA), calibration of $\mathrm{pH}$-meter was carried out with buffers of known concentrations $(\mathrm{pH}=4$ and $\mathrm{pH}=7)(14)$.

\section{Results}

For the determination of the metal content in the samples of dandelion, the calibration method was used. The basic calibration parameters for each test element were determined using deionized water for the concentration of zero and standard solutions of the corresponding concentrations obtained by diluting the base reference multi-elemental standard. Parameters of the analytical calibration curves such as wavelength $\lambda$, limits of detection and quantification (LOD and LOQ), correlation coefficient $\mathrm{R}^{2}$, intercept (b), slope (m), average RSD for repeatability of calibration solutions measurements are shown in Table 3. 
Table 3. Parameters of the analytical calibration curves: wavelength $\lambda(\mathrm{nm})$,

limits of detection and quantification (LOD and LOQ, ppm), correlation coefficient ( $r$ ), intercept (b), slope (m), average RSD (\%) for repeatability of calibration solutions measurements

\begin{tabular}{|cccccccc||}
\hline \hline Element & $\boldsymbol{\Lambda}(\mathbf{n m})$ & LOD $(\mathbf{p p m})$ & LOQ $\mathbf{( p p m )}$ & $\mathbf{r}$ & $\mathbf{b}$ & $\mathbf{m}$ & RSD (\%) \\
\hline \hline $\mathrm{Cd}$ & 228.802 & 0.0828 & 0.2759 & 0.999946 & 0.76 & 1906 & 4.07 \\
$\mathrm{Cu}$ & 324.754 & 0.1181 & 0.3936 & 0.999889 & 46.67 & 6072 & 8.22 \\
$\mathrm{~Pb}$ & 220.353 & 0.2191 & 0.7304 & 0.999619 & 0.09 & 153 & 0.87 \\
$\mathrm{Zn}$ & 202.548 & 0.0779 & 0.2598 & 0.999952 & 5.33 & 9825 & 1.98 \\
\hline
\end{tabular}

The applied ICP-OES technique allows the element to be viewed at different wavelengths. All analytes were determined on four wavelengths. In this way, it is possible for each element to select the wavelength at which the spectral and matrix inter- ferences are minimized (15). The optimal wavelength for each of the detected elements is determined by comparing the inclination of the corresponding calibration curves.

Table 4. The metal content $(\mathrm{mg} / \mathrm{kg})$ in dandelion leaves samples collected from selected locations

\begin{tabular}{||ccccc||}
\cline { 2 - 5 } \multicolumn{1}{c|}{} & \multicolumn{4}{c||}{ The metal content \pm SD } \\
\hline \hline Site & Cd & Cu & Pb & Zn \\
\hline $1 a$ & $0.25 \pm 0.01$ & $20.02 \pm 1.23$ & $0.48 \pm 0.02$ & $62.71 \pm 1.56$ \\
$1 b$ & $0.27 \pm 0.02$ & $24.11 \pm 1.09$ & $0.33 \pm 0.03$ & $58.16 \pm 1.27$ \\
\hline $2 a$ & $0.22 \pm 0.02$ & $17.83 \pm 1.12$ & $0.39 \pm 0.05$ & $48.36 \pm 1.38$ \\
$2 b$ & $0.18 \pm 0.01$ & $19.22 \pm 1.37$ & $0.41 \pm 0.03$ & $52.88 \pm 1.52$ \\
\hline $3 a$ & $0.22 \pm 0.01$ & $18.23 \pm 1.03$ & $0.52 \pm 0.11$ & $51.18 \pm 1.09$ \\
$3 b$ & $0.21 \pm 0.01$ & $21.12 \pm 1.29$ & $0.49 \pm 0.08$ & $49.35 \pm 1.17$ \\
\hline $4 a$ & $0.29 \pm 0.01$ & $16.25 \pm 1.11$ & $0.54 \pm 0.09$ & $57.26 \pm 1.27$ \\
$4 b$ & $0.32 \pm 0.02$ & $14.32 \pm 1.03$ & $0.47 \pm 0.10$ & $56.27 \pm 1.09$ \\
\hline $5 a$ & $0.36 \pm 0.02$ & $24.07 \pm 1.01$ & $1.84 \pm 0.02$ & $56.28 \pm 1.86$ \\
$5 b$ & $0.32 \pm 0.01$ & $19.72 \pm 1.26$ & $1.51 \pm 0.09$ & $48.39 \pm 1.62$ \\
\hline $6 a$ & $0.49 \pm 0.02$ & $22.12 \pm 0.98$ & $2.03 \pm 0.04$ & $59.01 \pm 2.41$ \\
$6 b$ & $0.44 \pm 0.03$ & $24.52 \pm 1.27$ & $1.88 \pm 0.12$ & $56.58 \pm 1.88$ \\
\hline 7 & $0.15 \pm 0.02$ & $9.72 \pm 0.68$ & $0.26 \pm 0.04$ & $44.68 \pm 1.87$ \\
8 & $0.13 \pm 0.01$ & $11.14 \pm 0.92$ & $0.15 \pm 0.03$ & $34.08 \pm 1.07$ \\
9 & $0.09 \pm 0.02$ & $9.25 \pm 0.74$ & $0.18 \pm 0.03$ & $36.12 \pm 1.41$ \\
\hline
\end{tabular}

Table 5. The metal content $(\mathrm{mg} / \mathrm{kg})$ in soil samples collected from selected locations

\begin{tabular}{||ccccc|c||}
\cline { 2 - 5 } \multicolumn{1}{c|}{} & \multicolumn{4}{c|}{ The metal content \pm SD } & \multirow{2}{*}{ pH } \\
\hline \hline Site & $\mathbf{C d}$ & $\mathbf{C u}$ & $\mathbf{P b}$ & Zn & \\
\hline $1 a$ & $0.41 \pm 0.12$ & $32.22 \pm 2.08$ & $22.34 \pm 1.12$ & $98.12 \pm 2.80$ & 7.61 \\
$1 b$ & $0.42 \pm 0.13$ & $33.16 \pm 1.86$ & $21.56 \pm 1.23$ & $96.20 \pm 3.38$ & 7.52 \\
\hline $2 a$ & $0.50 \pm 0.11$ & $28.70 \pm 1.12$ & $32.65 \pm 1.17$ & $101.37 \pm 3.22$ & 7.38 \\
$2 b$ & $0.50 \pm 0.12$ & $29.10 \pm 1.18$ & $31.30 \pm 1.45$ & $100.04 \pm 4.15$ & 7.35 \\
\hline $3 a$ & $0.38 \pm 0.10$ & $25.19 \pm 2.12$ & $27.75 \pm 1.16$ & $108.63 \pm 3.60$ & 7.56 \\
$3 b$ & $0.38 \pm 0.15$ & $24.66 \pm 1.75$ & $28.02 \pm 1.04$ & $107.22 \pm 2.44$ & 7.48 \\
\hline $4 a$ & $0.46 \pm 0.08$ & $22.46 \pm 1.11$ & $25.85 \pm 1.24$ & $98.67 \pm 5.17$ & 7.60 \\
$4 b$ & $0.48 \pm 0.13$ & $24.20 \pm 1.06$ & $25.10 \pm 1.05$ & $99.04 \pm 4.35$ & 7.63 \\
\hline $5 a$ & $0.60 \pm 0.12$ & $34.69 \pm 1.09$ & $28.55 \pm 1.30$ & $126.52 \pm 3.20$ & 7.52 \\
$5 b$ & $0.61 \pm 0.15$ & $35.26 \pm 1.35$ & $29.06 \pm 1.12$ & $125.20 \pm 2.18$ & 7.48 \\
\hline $6 a$ & $0.67 \pm 0.21$ & $30.97 \pm 1.71$ & $38.28 \pm 1.52$ & $120.88 \pm 5.17$ & 7.28 \\
$6 b$ & $0.66 \pm 0.17$ & $29.56 \pm 2.05$ & $37.76 \pm 1.13$ & $121.02 \pm 4.35$ & 7.30 \\
\hline 7 & $0.33 \pm 0.11$ & $8.58 \pm 1.36$ & $8.49 \pm 0.09$ & $92.13 \pm 4.12$ & 7.59 \\
8 & $0.28 \pm 0.09$ & $12.71 \pm 2.02$ & $7.10 \pm 0.14$ & $75.76 \pm 3.92$ & 7.48 \\
9 & $0.17 \pm 0.02$ & $9.05 \pm 1.16$ & $3.27 \pm 0.16$ & $53.52 \pm 4.37$ & 6.69 \\
\hline
\end{tabular}


The obtained values of the content of the detected metals in the dandelion samples, sampled from different localities, as well as the corresponding standard deviations, are shown in Table 4.The contents of the detected metals are shown as the mean value (milligram per kilogram of the test sample, $\mathrm{mg} / \mathrm{kg}$ ) obtained for three successive measurements.

The soil is one of the major pathways for metal absorption by plants, for this reason, in this study, the soil underlaying the tested dandelion leaves samples was analyzed.

Availability of metals from soil for a plant, that is, its root, depends on the ability of metals to absorb, desorb and complex with one of the components in the soil matrix. These processes are conditioned by soil characteristics such as $\mathrm{pH}$, composition and soil structure. Heavy metal mobility is higher in soil with a lower $\mathrm{pH}$ value.

The metal concentration in the soil samples and $\mathrm{pH}$ values are presented in Table 5 . The contents of the detected metals are shown as the mean value (milligram per kilogram of the test sample, $\mathrm{mg} / \mathrm{kg}$ ) obtained for three successive measurements.

\section{Discussion}

Cadmium is an element that is not a part of any compound that has a metabolic significance, and also belongs to the most dangerous environmental pollutants. Plants adopt cadmium mainly through the root, because this heavy metal has great mobility through the soil on which the plant grows (3). It is considered that the normal $\mathrm{Cd}$ concentration in plant tissue is between 0.2 and 0.8 $\mathrm{mg} / \mathrm{kg}$, while the contents of this metal of 5 to 30 $\mathrm{mg} / \mathrm{kg}$ are considered to be toxic $(3,16)$.

Small amounts of copper are essential for plant growth, and this element also makes the structure of many enzymes. The phytotoxic level of this metal is $30 \mathrm{mg} / \mathrm{kg}$ (18). The normal content of $\mathrm{Cu}$ in plants is about $4-15 \mathrm{mg} / \mathrm{kg}$, while the contents of this element over $25 \mathrm{mg} / \mathrm{kg}$ are toxic to the plant (16).

Lead is an element that can be delivered to the plants either by soil or by air. The normal contents of this metal in plants range from 0.1 to 10 $\mathrm{mg} / \mathrm{kg}$. The toxic contents of $\mathrm{Pb}$ are from 30 to 300 $\mathrm{mg} / \mathrm{kg}(16)$.

Zinc is an essential component for a large number of ( $>300$ ) enzymes involved in the synthesis and decomposition of carbohydrates, lipids, proteins and nucleic acids, as well as in the metabolism of other micronutrients. $\mathrm{Zn}$ is an element that is not considered to be highly toxic and toxin levels of this metal (300-400 mg/kg), depending on both the plant species and its level of maturity. High zinc content in plants can cause leaf losses, while on the other hand Zn deficiency leads to their deformation. It is believed that the environment is contaminated with zinc when the content of this element, detected in plants, is about $100 \mathrm{mg} / \mathrm{kg}$ (16).

The content of cadmium and lead, as the two most toxic metals in the group of determined ele- ments, which are detected in this study, ranged from 0.09 to $0.15 \mathrm{mg} / \mathrm{kg}$ (Cd) and 0.15 to 0.26 $\mathrm{mg} / \mathrm{kg}(\mathrm{Pb})$ for samples collected in the no traffic impacted areas, i.e., from 0.18 to $0.49 \mathrm{mg} / \mathrm{kg}$ (Cd) and from 0.33 to $2.03 \mathrm{mg} / \mathrm{kg}$ in samples that were impacted by motor traffic (Table 4). Regarding to the content of detected metals ( $\mathrm{Cd}$ and $\mathrm{Pb}$ ), in dandelion samples from different locations, it can clearly be seen, that exposure to one of the sources of pollution (traffic, petrol pump, trapping) contributes to the increase of these pollutants in the dandelion plant tissue in relation to samples that were not exposed to the effects of the pollutant of the environment.

The results of this study are in line with the conclusions presented by other authors, that the content of cadmium and lead in the dandelion leaves is lower in samples taken from sites that were protected from traffic (Parks and Natural Parks), in relative to the contents detected in the samples that were impacted by the source of these heavy metals $(4,5,10,11)$.

According to Kloke et al. (17) and Kabata and Pendias (4), the normal contentration of $\mathrm{Cd}$ in plants are $0.2-0.8 \mathrm{mg} / \mathrm{kg}$ and $0.1-10 \mathrm{mg} / \mathrm{kg}$ for $\mathrm{Pb}$. Results for $\mathrm{Cd}$ and $\mathrm{Pb}$ in this study corresponded to those values. That indicates that detected contents in this paper are below to the toxic limit for those pollutants in analyzed dandelion species.

However, the given fact is that dandelion can also be used mainly as a salad in human nutrition, the contents of $\mathrm{Cd}$ and $\mathrm{Pb}$ detected in this study are compared to the maximum allowed content of these metals in the fresh dandelion leaves $(0.2 \mathrm{mg} / \mathrm{kg}$ for $\mathrm{Cd}$ and $0.3 \mathrm{mg} / \mathrm{kg}$ for $\mathrm{Pb}$ ) prescribed by the World Health Organization (WHO) (1). In all samples of dandelion taken from the sites impacted to the pollutants, the contents of cadmium and lead were above the maximum allowed (Table 4), while the contents of these metals in the dandelion leaves taken from locations that were not exposed to the sources of contamination were below the prescribed limits for this plant species. Detected contents of $\mathrm{Cd}$ and $\mathrm{Pb}$ in this study, in samples from uncontaminated sites, are low, but due to the cumulative effect these metals have, as well as due to their ability to deposit in the vital organs of humans, it is necessary to monitor the content of these metals in the dandelion plant, which are used in human nutrition. As this plant species has the ability to accumulate $\mathrm{Cd}$ and $\mathrm{Pb}$ from the environment, particular attention should be paid to the location from which dandelion is taken, and if used for the human nutrition, the plant has to be taken from sites that are not impacted by motor traffic and other environment pollutants.

The content of copper and zinc in the tested dandelion samples ranged from 9.25 to 11.14 $\mathrm{mg} / \mathrm{kg}(\mathrm{Cu})$ and from 34.08 to $44.68 \mathrm{mg} / \mathrm{kg}(\mathrm{Zn})$ from uncontaminated sites relative to the content of these elements from the sites that were exposed to the source of pollutants, which ranged from 14.32 to $24.52 \mathrm{mg} / \mathrm{kg}$ (Cu) or from 48.36 to $62.71 \mathrm{mg} / \mathrm{kg}$ $(\mathrm{Zn})$. As in the instance of $\mathrm{Cd}$ and $\mathrm{Pb}$, the content of $\mathrm{Cu}$ and $\mathrm{Zn}$ was higher in dandelion samples that were sampled near the source of pollution compared 
to samples that were not exposed to the effects of these sources.

These results confirmed that elevated contents of some metals can be found in the dandelion leaves, if this plant species is exposed to the source of the pollutant. The concentration of $\mathrm{Cu}$ and $\mathrm{Zn}$ in the samples tested was lower than that which would be toxic to this plant species (16).

By comparing $\mathrm{Cd}, \mathrm{Cu}, \mathrm{Pb}$, and $\mathrm{Zn}$ content in analyzed dandelion samples taken at two different distances ( $1 \mathrm{~m}$ and $5 \mathrm{~m}$ ) from the sites that were exposed to sources of pollution, samples 1-6 (Table 4 ), it can be seen that there is no regular trend of concentration of detected metals in this study, with the distance from the source of pollution. This is not in agreement with the authors who perceived such a trend in their studies $(2,5,6,8,18)$ but it is in agreement with the Gicomina et al. study where there was also no correlation between metal content and distance from source of pollution (1). This may be due to the fact that such studies regarded point sources of pollution and/or that the total distance from the street considered in our research (max of $5 \mathrm{~m})$ was too short.

The soil is one of the major pathway for metal accumulation in plants, because of that, in this study was analyzed the soil underlaying the dandelion samples.

The content of metals detected in the soil is given in Table 5, while Table 6 gives the maximum limit values, remediation values and maximum permissible values of $\mathrm{Cd}, \mathrm{Pb}, \mathrm{Cu}$ and $\mathrm{Zn}$ content in the soil, which are prescribed by the respective Regulations and Regulation of the Republic of Serbia (19, 20).

Table 6. Maximum limit, remediation and maximum permissible values of $\mathrm{Cd}, \mathrm{Cu}, \mathrm{Pb}$ and $\mathrm{Zn}$ in the soil expressed as $\mathrm{mg} / \mathrm{kg}$

\begin{tabular}{||cccc||}
\hline \hline Metals & Maximum limit values & Remediation values & $\begin{array}{c}\text { Maximum permissible } \\
\text { values }\end{array}$ \\
\hline \hline $\mathrm{Cd}$ & 0.8 & 12 & up to 3 \\
$\mathrm{Cu}$ & 36 & 190 & up to 100 \\
$\mathrm{~Pb}$ & 85 & 530 & up to 100 \\
$\mathrm{Zn}$ & 140 & 720 & up to 300 \\
\hline
\end{tabular}

Regarding the detected content of $\mathrm{Cd}, \mathrm{Cu}, \mathrm{Pb}$ and $\mathrm{Zn}$ in the soil samples, it can be seen that the concentrations of these metals are higher in soil sampled from the sites that are exposed to the pollutants, compared to those soil samples from locations that are not near polluted sources (Table 5). Also, the content of detected metals in all tested soil samples is below the maximum limit values prescribed by the legislation of the Republic of Serbia (Table 6).

The soil's metal availability for the plant, i.e., its root, depends on the ability of the metal to adsorb, desorb, and compile with one of the components in the soil matrix. These processes are conditioned by soil characteristics such as $\mathrm{pH}$, composition and soil structure.

The results of the $\mathrm{pH}$ measurement of the soil samples are part of Table 5 . It can be seen that the samples are mildly basic to neutral. The lowest $\mathrm{pH}$ value of all samples shows the soil from location 9 and this value was 6.69. The soil $\mathrm{pH}$ value is very important for the mobility of the metal ions in it, and therefore for the resorption of plants. Namely, if the value of the $\mathrm{pH}$ of the soil is lower, the soil is more acidic, and the mobility of the metal ion is higher.

Based on the obtained results (Table 5), it can be seen that soil samples from contaminated sites had higher content of detected metals regarding the soil sampled from locations that were not impacted by the source of contamination. According to this, it can be concluded that proximity to the source of pollution increases the content of de- tected metals in the soil on which the analyzed plant species grows.

\section{Conclusion}

The results of this study have shown that dandelion leaves can provide a good data of environmental pollution, because the content of detected metals ( $\mathrm{Cd}, \mathrm{Cu}, \mathrm{Pb}$ and $\mathrm{Zn}$ ) was higher in samples that were exposed to the negative effect of environmental pollutants compared to those samples that were not under the influence of pollution's sources. The metal concentration in the samples of dandelion leaves is proportional to urbanization, industrial activity, and density of traffic.

The content of detected metals in all dandelion samples was below the level that would be considered toxic to this plant species.

The amount of $\mathrm{Cd}, \mathrm{Cu}, \mathrm{Pb}$ and $\mathrm{Zn}$ in soil samples was higher in soil exposed to atmospheric and exhaust gas pollution, compared to samples that were not under this negative impact. The content of detected metals in soil samples was below the maximum limit values prescribed by the legislation of the Republic of Serbia.

The increased content of detected metals in the samples of dandelion that were under the influence of the pollutant, may be the result of a synergistic effect, soil on which this plant species thrives and the air that is contaminated by the effects of motor traffic and other forms of pollutants. 
As dandelion is used in human nutrition, and since heavy metals with cumulative and toxic effects have been detected in it, $\mathrm{Pb}$ and $\mathrm{Cd}$, it is necessary, in order to protect human health, to check the content of these metals in the dandelion used in human nutrition. Also, due to the ability of this plant species to adsorb $\mathrm{Pb}$ and $\mathrm{Cd}$, if it is additionally exposed to them, it is necessary to take into account from which site this plant species is taken for nutrition.

The ICP-OES method proved to be a good method for determining the content of cadmium, copper, lead and zinc in this type of samples.

\section{Acknowledgment}

Results are part of the projects $N^{O}$ TR33034 financially supported by the Ministry of Education, Science and Technological Development of the Republic of Serbia.

\section{References}

1. Giacomino A, Malandrino $M$, Colombo $M L$, Miaglia $S$, Maimone $\mathrm{P}$, Blancato $\mathrm{S}$, et al. Metal content in dandelion (Taraxacum officinale) leaves: influence of vehicular traffic and safety upon consumption as food. J Chem 2016; 1-9. [CrossRef]

2. Keane B, Collier MH, Shann JR, Rogstad SH. Metal content of dandelion (Taraxacum officinale) leaves in relation to soil contamination and airborne particulate matter. Sci of Tot Environ 2001;281(1-3):63-78.

[CrossRef] [PubMed]

3. Kabata-Pendias A, Pendias $\mathrm{H}$. Trace elements in soils and plants CRC Press Inc. Florida (FL): Boca Raton; 2001. [CrossRef]

4. Kuleff I, Djingova R. The dandelion (Taraxacum officinale)-amonitor for environmental pollution? Water Air Soil Pollut 1984; 21(1):77-85. [CrossRef]

5. Kabata-Pendias A., Dudka S. Trace metal contents of Taraxacum officinale (dandelion) as a convenient environmental indicator. Environ Geochem Health 1991;13(2):108-13. [CrossRef] [PubMed]

6. Kovac P. Heavy metal accumulation by ruderal and cultivated plants in a heavily polluted district of Budapest. Plants as Biomonitors 1993; 495-505.

7. Winter S. Biomonitoring in Stadten mit Taraxacum officinale Web.(Loewenzahn)-Eine Studie in der Stadt Zittau, Sachsen. Okotoxicologie/Okosystemare Ansatze und Methoden 1999; 238-47.

8. Marr $\mathrm{K}$, Fyles $\mathrm{H}$, Hendershot W. Trace metals in montreal urban soils and the leaves of Taraxacum officinale. Can J Soil Sci 1999;79(2):385-7. [CrossRef]

9. Djingova R, Kuleff I. Seasonal variations in the metal concentration of Taraxacum officinale, Plantago major and Plantago lanceolata. Chem Ecol 1999; 16(2):23953. [CrossRef]

10. Krolak E. Accumulation of $\mathrm{Zn}, \mathrm{Cu}, \mathrm{Pb}$ and $\mathrm{Cd}$ by Dandelion (Taraxacum officinale Web.) in environments with various degrees of metallic contamination. Pol J Environ Stud 2003; 12(6):713-21.
11. Djingova R, Kuleff I, Andreev N. Comparison of the ability of several vascular plants to reflect environmental pollution. Chemosphere 1993;27(8):1385-96. [CrossRef]

12. Mitra $S$, editor. Sample preparation techniques in analytical chemistry. John Wiley \& Sons; 2004. [CrossRef]

13. Jamali MK, Kazi TG, Arain MB, Afridi HI, Jalbani N, Memon AR. Heavy metal contents of vegetables grown in soil, irrigated with mixtures of wastewater and sewage sludge in Pakistan, using ultrasonic-assisted pseudo-digestion. J Agron Crop Sci 2007;193(3):218-28. [CrossRef]

14. EPA method $9045 \mathrm{~d}$ : Soil and Waste $\mathrm{pH}$.

15. BossCB, Kenneth JF. Concepts, instrumentation and techniques in inductively coupled plasma optical emission spectrometry. Norwalk: Perkin Elmer, 2004.

16. Gjorgieva D, Kadifkova-Panovska T, Bačeva K, Stafilov T. Assessment of heavy metal pollution in Republic of Macedonia using a plant assay. Arch Environ Contam Toxicol 2011;60(2):233-40. [CrossRef] [PubMed]

17. Kloke A, Sauerbeck DR, Vetter H. The contamination of plants and soils with heavy metals and the transport of metals in terrestrial food chains. InChanging metal cycles and human health 1984;11341. Berlin (GE): Springer. [CrossRef]

18. Czarnowska K, Milewska A. The content of heavy metals in an indicator plant (Taraxacum officinale) in Warsaw. Pol J Environ Stud 2000;9(2):125-8.

19. Službeni glasnik R. Srbije br. 30/2018. Uredba o graničnim vrednostima zagađujućih, štetnih i opasnih materija u zemljištu.

20. Službeni glasnik R. Srbije br. 23/1994. Pravilnik o dozvoljenim količinama opasnih i štetnih materija u zemljištu i vodi za navodnjavanje i metodama njihovog ispitivanja. 


\title{
ODREĐIVANJE SADRŽAJA KADMIJUMA, BAKRA, OLOVA I CINKA U LISTOVIMA MASLAČKA (TARAXACUM OFFICINALE WEBB.) I ZEMLIŠTU ICP-OES METODOM
}

\author{
Dragan Velimirović ${ }^{1}$, Biljana Kaličanin ${ }^{1}$, Milan Stojković ${ }^{2}$, Snežana Tošić ${ }^{2}$
}

\begin{abstract}
Kontakt: Dragan Velimirović
Bulevar dr Zoran Đinđić 81, 18000 Niš, Srbija

E-mail: dragan.velimirovic@medfak.ni.ac.rs
\end{abstract}

${ }^{1}$ Univerzitet u Nišu, Medicinski fakultet, Odsek za farmaciju, Niš, Srbija

'Univerzitet u Nišu, Prirodno-matematički fakultet, Odsek za hemiju, Niš, Srbija

Maslačak (Taraxacum officinale Webb.) je biljna vrsta koja može da akumulira određenu količinu metala. Cilj ove studije bio je da se odredi sadržaj $\mathrm{Cd}, \mathrm{Cu}, \mathrm{Pb}$ i Zn u listovima maslačka i zemljištu, koji su uzorkovani sa različitih lokaliteta. Jedna grupa uzoraka bila je izložena uticaju izvora zagađenja ovih metala, dok druga grupa nije bila pod uticajem zagađivača. Količina metala u ispitivanim uzorcima određena je primenom tehnike indukovano kuplovane plazme optički emisione spektrometrije (ICP-OES). Sadržaj detektovanih metala bio je veći u uzorcima lista maslačka i zemljišta koji su bili izloženi negativnom uticaju zagađivača životne sredine, u odnosu na one uzorke koji nisu bili pod uticajem ovih izvora zagađenja. Povećani sadržaj detektovanih metala u uzorcima listova maslačka, koji su bili pod uticajem štetnog dejstva zagađivača, može biti rezultat sinergističkog efekta zemljišta, na kome ova biljna vrsta uspeva i vazduha, koji je zagađen motornim saobraćajem i drugim vidovima zagađenja. Rezultati ove studije pokazali su da maslačak, na osnovu količine detektovanih metala u biljnom tkivu, može pružiti podatke o zagađenju životne sredine. Kako se maslačak koristi u ljudskoj ishrani, a kako su u listu ove biljne vrste detektovani teški metali ( $\mathrm{Pb}$ i $\mathrm{Cd}$ ), koji imaju kumulativno i toksično dejstvo, neophodno je, u cilju zaštite ljudskog zdravlja, proveravati prisustvo i sadržaj ovih metala u maslačku koji se koristi u ljudskoj ishrani.

Acta Medica Medianae 2020;59(1):23-30.

Ključne reči: maslačak, metali, zemljište, zagađivači, ICP-OES 